\author{
Magdalena Ataman \\ Dr inż. \\ Wydział Inżynierii Lądowej, \\ Politechnika Warszawska \\ m.ataman@il.pw.edu.pl \\ Wacław Szcześniak \\ Prof. dr hab. inż. \\ Wydział Inżynierii Lądowej, \\ Politechnika Warszawska \\ w.szczesniak@il.pw.edu.pl
}

DOI: 10.35117/A_ENG_19_11_04

\title{
Vibrations of the plate with elastic core resting on the Winkler foundation caused by a moving oscillator
}

\begin{abstract}
In the paper a structure consisting of two Kirchhoff plates connected by an elastic Winkler layer is considered. The structure rests on the Winkler foundation and is subjected to a one-mass visco-elastic oscillator, moving at a constant speed on the upper plate, parallel to one of the plate sides. Forced and free vibrations of the plates and the oscillator are analysed. In the case of such a complex system vibration of the plates is described by two coupled differential equations, or one differential equation with elevated order. In addition, due to the nature of the moving load (inertial load), these equations have variable, time-dependent coefficients. The solutions are illustrated by numerical examples.
\end{abstract}

Keywords: Vibration of plate with elastic core; Winkler foundation; Moving oscillator

\section{Introduction}

Layered structures, especially plates, are widely used in road, bridge and airport construction. There are many papers in the literature on issues of beams and sandwich panels. These studies include both monographs, review papers and original scientific dissertations. Beams and sandwich panels are the subjects of analysis, among others, in works [1-10]. They analyze the problems of moving loads, moderately high deflections, thermal influences, elastic substrate influences, physical nonlinearity of the material and other.

The purpose of this work is to present a dynamic analysis of a sandwich panel resting on a deformable substrate under a load of a moving one-mass oscillator. We consider two plates connected by a layer of elastic Winkler filling. The discussed system rests on Winkler's foundation. The structure is loaded with a one-mass visco-elastic oscillator moving at a constant speed on the upper plate, parallel to the $x_{1}$ axis (Fig. 1). The work analyzes forced vibrations and free vibrations of the plate and oscillator system. 


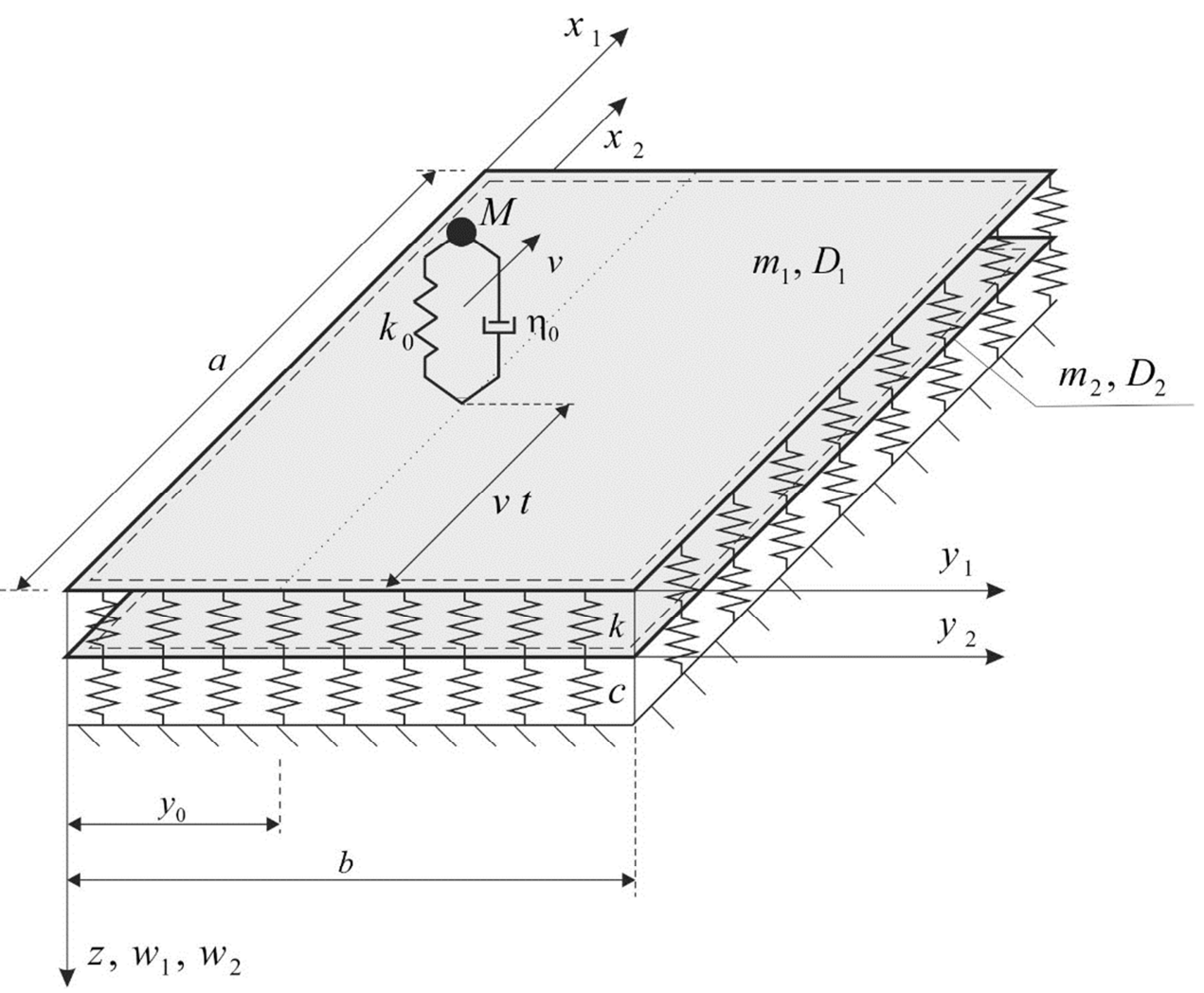

1. Dynamic diagram of the plate arrangement - Winkler elastic foundation loaded with a moving one-mass oscillator

\section{Equations of oscillator motion and plate arrangement on Winkler's foundation}

We consider small vibrations of a rectangular plate consisting of three layers, resting on a Winkler foundation with a coefficient of elasticity (Fig. 1). The upper and lower layers are made of homogeneous, elastic, thin Kirchhoff plates with a thickness of $h_{1}$, and $h_{2}$. Uniformly distributed unit weights and stiffness of these plates are respectively $m_{1}$ and $D_{1}$ and $m_{2}$, and $D_{2}$. The plates are connected with a Winkler elastic filling with a coefficient of elasticity $k$. The filling only transfers compression or stretching. The load on the system is a one-mass mobile oscillator with a mass $M$, moving on the upper surface of the plate, parallel to the $x_{1}$ axis at a constant speed $v$. The deflection of the central surface of the upper plate describes the coordinate $w_{1}$, the central surface of the lower plate the coordinate $w_{2}$, and the deflection of the oscillator mass the coordinate $w$.

The vibrating motion of the sandwich panel system - one-mass oscillator, in the case when the oscillator moves on the panel parallel to the axis, is described by the following differential equations:

$$
\begin{aligned}
& M \frac{\mathrm{d}^{2} w}{\mathrm{~d} t^{2}}+\eta_{0}\left(\frac{\mathrm{d} w}{\mathrm{~d} t}-\frac{\mathrm{d} w_{1}}{\mathrm{~d} t}\right)+k_{0}\left(w-w_{1}\right)=0, \\
& D_{1} \nabla^{4} w_{1}(x, y, t)+m_{1} \frac{\mathrm{d}^{2} w_{1}(x, y, t)}{\mathrm{d} t^{2}}+k\left[w_{1}(x, y, t)-w_{2}(x, y, t)\right]=p_{1}(x, y, t), \\
& D_{2} \nabla^{4} w_{2}(x, y, t)+m_{2} \frac{\mathrm{d}^{2} w_{2}(x, y, t)}{\mathrm{d} t^{2}}+k\left[w_{2}(x, y, t)-w_{1}(x, y, t)\right]+c w_{2}(x, y, t)=0,
\end{aligned}
$$


where:

$p_{1}(x, y, t)=N(t) \delta(x-v t) \delta\left(y-y_{0}\right)=\left[M g-M \frac{\mathrm{d}^{2} w}{\mathrm{~d} t^{2}}\right] \delta(x-v t) \delta\left(y-y_{0}\right)$.

In the above formulas $N(t)$, it is the dynamic pressure of the moving single-mass oscillator on the plate.

The material derivative in equations (1), in the case of constant oscillator speed, is given by the following formula:

$\frac{\mathrm{d} w_{1}}{\mathrm{~d} t}=\frac{\partial w_{1}}{\partial t}+v \frac{\partial w_{1}}{\partial x}$

The first of equations (1) is the equation of the visco-elastic one-mass oscillator relative to the position of static equilibrium. The relationship (2) was used in the oscillator's motion equation. Differential equations of motion (1) of the three-layer system under consideration are fourth-order partial equations due to geometric variables $x$ and $y$ and the second due to time $t$. These equations are linked with each other.

The solution of equations of plate movement loaded with a moving oscillator

Coupled differential equations of the movement of the upper and lower plates (1) can be reduced to two independent equations with one unknown $w_{1}$ or $w_{2}$. Unknown deflections $w_{1}$ and $w_{2}$ are related by the relation resulting from the third equation (1):

$$
w_{1}(x, y, t)=\left(1+\frac{c}{k}\right) w_{2}(x, y, t)+\frac{D_{2}}{k} \nabla^{4} w_{2}(x, y, t)+\frac{m_{2}}{k} \frac{\partial^{2} w_{2}(x, y, t)}{\partial t^{2}} .
$$

Using (2) in the first equation (1) and substituting (3) for the first two equations (1), we obtain a system of two equations describing the oscillator and lower plate motion in the following form: 


$$
\begin{aligned}
& M \frac{\mathrm{d}^{2} w}{\mathrm{~d} t^{2}}+\eta_{0}\left\langle\frac{\mathrm{d} w}{\mathrm{~d} t}-\left\{\left(1+\frac{c}{k}\right) \frac{\partial w_{2}}{\partial t}+\frac{D_{2}}{k} \nabla^{4}\left(\frac{\partial w_{2}}{\partial t}\right)+\frac{m_{2}}{k_{1}} \frac{\partial^{3} w_{2}}{\partial t^{3}}+\right.\right. \\
& \left.\left.+v\left[\left(1+\frac{c}{k}\right) \frac{\partial w_{2}}{\partial x}+\frac{D_{2}}{k} \nabla^{4}\left(\frac{\partial w_{2}}{\partial x}\right)+\frac{m_{2}}{k} \frac{\partial^{3} w_{2}}{\partial t^{2} \partial x}\right]\right\}\right)+ \\
& +k_{0}\left\{w-\left[\left(1+\frac{c}{k}\right) w_{2}+\frac{D_{2}}{k} \nabla^{4} w_{2}+\frac{m_{2}}{k} \frac{\partial^{2} w_{2}}{\partial t^{2}}\right]\right\}=0, \\
& \frac{D_{1} D_{2}}{k} \nabla^{4}\left(\nabla^{4} w_{2}\right)+\frac{1}{k}\left(D_{1} m_{2}+D_{2} m_{1}\right) \nabla^{4}\left(\frac{\partial^{2} w_{2}}{\partial t^{2}}\right)+\left[D_{1}\left(1+\frac{c}{k}\right)+D_{2}\right] \nabla^{4} w_{2}+ \\
& +\left[m_{1}\left(1+\frac{c}{k}\right)+m_{2}\right] \frac{\partial^{2} w_{2}}{\partial t^{2}}+\frac{m_{1} m_{2}}{k} \frac{\partial^{4} w_{2}}{\partial t^{4}}+c w_{2}= \\
& =\left[M g-M \frac{\partial^{2} w}{\partial t^{2}}\right] \delta(x-v t) \delta\left(y-y_{0}\right) .
\end{aligned}
$$

The equation describing the vibration of the lower plate (4) 2 is the eighth order differential equation and remains coupled with the oscillator equation (4) 1, which is the fifth order.

We look for solutions to the system of equations (4) by separating Fourier variables assuming a solution in the form of a double series:

$w_{2}(x, y, t)=\sum_{m=1}^{\infty} \sum_{n=1}^{\infty} f_{m n}(t) \sin \alpha_{m} x \sin \beta_{n} y,(5)$

where:

$\alpha_{m}=\frac{m \pi}{a}, \beta_{n}=\frac{n \pi}{b}$,

$f_{m n}(t)$ - an unknown time-dependent function.

Then we use the orthogonalization algorithm to solve the oscillator and plate motion equations taking into account only one word of the double series $m=n=1$. We write the equations of oscillator and upper plate movement in dimensionless form as follows:

$$
\begin{aligned}
& \frac{\mathrm{d}^{2} q_{0}(\xi)}{\mathrm{d} \xi^{2}}+\frac{\eta_{0} a}{M v} \frac{\mathrm{d} q_{0}(\xi)}{\mathrm{d} \xi}+\frac{k_{0} a^{2}}{M v^{2}} q_{0}(\xi)= \\
& =\sin \pi \eta \frac{w_{2}^{\mathrm{st}}}{w^{\mathrm{st}}}\left[\frac{\eta_{0} m_{2} v}{M k a} \sin \pi \xi \frac{\mathrm{d}^{3} q_{11}(\xi)}{\mathrm{d} \xi^{3}}+\frac{m_{2}}{M k}\left(\eta_{0} v \frac{\pi}{a} \cos \pi \xi+k_{0} \sin \pi \xi\right) \frac{\mathrm{d}^{2} q_{11}(\xi)}{\mathrm{d} \xi^{2}}+\right. \\
& +\frac{\eta_{0} a}{M v}\left(1+\frac{c}{k}+\frac{D_{2}}{k} \gamma_{11}^{4}\right) \sin \pi \xi \frac{\mathrm{d} q_{11}(\xi)}{\mathrm{d} \xi}+ \\
& +\frac{a^{2}}{M v^{2}}\left(1+\frac{c}{k}+\frac{D_{2}}{k} \gamma_{11}^{4}\right)\left(\eta_{0} v \frac{\pi}{a} \cos \pi \xi+k_{0} \sin \pi \xi\right) q_{11}(\xi),
\end{aligned}
$$




$$
\begin{aligned}
& \frac{\mathrm{d}^{4} q_{11}(\xi)}{\mathrm{d} \xi^{4}}+\frac{k a^{2}}{v^{2} m_{1} m_{2}}\left[\frac{1}{k}\left(D_{1} m_{2}+D_{2} m_{1}\right) \gamma_{11}^{4}+m_{1}\left(1+\frac{c}{k}\right)+m_{2}\right] \frac{\mathrm{d}^{2} q_{11}(\xi)}{\mathrm{d} \xi^{2}}+ \\
& +\frac{k a^{4}}{v^{4} m_{1} m_{2}}\left\{\frac{D_{1} D_{2}}{k} \gamma_{11}^{8}+\left[D_{1}\left(1+\frac{c}{k}\right)+D_{2}\right] \gamma_{11}^{4}+2 c\right\} q_{11}(\xi)= \\
& =\frac{1}{w_{2}^{\text {st }}} \frac{4 k a^{3} \sin \pi \xi \sin \pi \eta}{b m_{1} m_{2} v^{4}}\left(M g-\frac{M v^{2}}{a^{2}} w^{\text {st }} \frac{\mathrm{d}^{2} q_{0}(\xi)}{\mathrm{d} \xi^{2}}\right),
\end{aligned}
$$

where:

$\xi=\frac{v t}{a}, \eta=\frac{y_{0}}{b}-$ dimensionless coordinates,

$w^{\text {st }}=\frac{M g}{k_{0}}-$ oscillator static deflection,

$w_{2}^{\text {st }}=\frac{4 M g}{a b\left\{\frac{D_{1} D_{2}}{k} \gamma_{11}^{8}+\left[D_{1}\left(1+\frac{c}{k}\right)+D_{2}\right] \gamma_{11}^{4}+2 c\right\}}-$ static deflection of the bottom plate center, caused by the weight of the oscillator, $q_{11}(\xi)$ - dimensionless deflection of the bottom plate, $q_{0}(\xi)$ - dimensionless vertical displacement of mass $M$ of the oscillator, $\gamma_{11}=\sqrt{\left(\frac{\pi}{a}\right)^{2}+\left(\frac{\pi}{b}\right)^{2}}$

The resulting dimensionless system of oscillator and bottom plate motion equations is a system of fourth order differential equations with variable coefficients with unknown functions $q_{0}(\xi)$ and $q_{11}(\xi)$. The solution of this system and graphic results can be obtained simply, e.g. using the MATHEMATICA program. The determined function $q_{11}(\xi)$ is a function of the deflection of the plate which is the bottom layer of the three-layer system. To obtain graphs of deflections of the upper plate, after determining the function $q_{11}(\xi)$, return to the coordinate $w_{2}(x, y, t)$, and then using the formula (3) calculate the function $w_{1}(x, y, t)$. The deflection of the upper layer of the plate $w_{1}(x, y, t)$ can also be represented in a dimensionless form, entering dimensionless coordinates $\xi$ and $\tilde{q}_{11}(\xi)$, where the function $\tilde{q}_{11}(\xi)$ should be referred to the static deflection of the lower plate, caused by the force $M g$ applied to the upper layer of the system.

Therefore, the solution of the system of three equations of motion brought down to the solution of the system of two differential equations of the eighth order due to geometric variables and the fourth due to time. Determining the deflections of both plates and the vertical displacement of the oscillator mass is also possible by solving the system of three partial differential equations of the fourth order due to variables and the second order due to time. These equations are linked with each other.

The solutions discussed above are valid when the moving oscillator is on the plate, i.e. when the dimensionless coordinate $\xi$ is in the range $0 \leq \xi \leq 1$.

After the oscillator rolls off the construction, at $\xi>1$ the plate vibrates freely. The free vibrations in the center of the bottom plate are described by the expression: 
$q_{11}^{\mathrm{sw}}(\xi)=\frac{w_{2}^{\mathrm{sw}}(t)}{w_{2}^{\mathrm{st}}}=\frac{1}{w_{2}^{\mathrm{st}}}\left(K_{1} \cos \omega_{11}^{(1)} t+L_{1} \sin \omega_{11}^{(1)} t+K_{2} \cos \omega_{11}^{(2)} t+L_{2} \sin \omega_{11}^{(2)} t\right)$

In the equation (7) $\omega_{11}^{(1)}$ and $\omega_{11}^{(2)}$ are the natural frequencies of the bottom plate:

$\omega_{11}^{(1)}=\sqrt{\frac{A-\sqrt{A^{2}-4 B}}{2}}$,
$\omega_{11}^{(2)}=\sqrt{\frac{A+\sqrt{A^{2}-4 B}}{2}}$

where:

$$
\begin{aligned}
& A=\frac{k}{m_{1} m_{2}}\left[\frac{1}{k}\left(D_{1} m_{2}+D_{2} m_{1}\right) \gamma_{11}^{4}+m_{1}\left(1+\frac{c}{k}\right)+m_{2}\right], \\
& B=\frac{D_{1} D_{2}}{m_{1} m_{2}} \gamma_{11}^{8}+\frac{k}{m_{1} m_{2}}\left[D_{1}\left(1+\frac{c}{k}\right)+D_{2}\right] \gamma_{11}^{4}+c .
\end{aligned}
$$

The considered plate is therefore a bimodal system. Equations (8) show that natural vibrations exist when the $A^{2}>4 B$ condition is met. In the case $A^{2}=4 B$, we receive an additional natural frequency band

$$
\omega_{11}^{(3)}=\sqrt{\frac{A}{2}} \cdot(9)
$$

In the considered task, the material parameters of the panels can be selected so that the upper panel does not have deflections. In this case, the bottom plate is a mechanical absorber of forced vibrations.

\section{Calculation example}

Because the considered system of motion equations (6) is a system of differential, linear, fourth order equations with variable coefficients, it was numerically solved using the Mathematica program. The following figures were used for the calculations:

- planned dimensions of the plates $a \times b=5,00 \mathrm{~m} \times 7,00 \mathrm{~m}$,

- top plate thickness $h_{1}=0,18 \mathrm{~m}$,

- modulus of elasticity of the upper plate $E_{1}=38600 \mathrm{MPa}$,

- top plate mass per unit area $m_{1}=4500 \mathrm{~kg} / \mathrm{m}^{2}$,

- upper plate Poisson's ratio $v_{1}=0,167$,

- bottom plate thickness $h_{2}=0,20 \mathrm{~m}$,

- modulus of elasticity of the bottom plate $E_{2}=23100 \mathrm{MPa}$,

- unit weight of the bottom plate $m_{2}=4000 \mathrm{~kg} / \mathrm{m}^{2}$,

- Poisson's ratio of the bottom plate $v_{2}=0,167$,

- coefficient of elasticity of the Winkler foundation $c=110 \mathrm{MN} / \mathrm{m}^{3}$,

- oscillator spring mass $M=11723 \mathrm{~kg}$, 
- oscillator damping coefficient $\eta_{0}=40 \mathrm{kNs} / \mathrm{m}$,

- oscillator coefficient of elasticity $k_{0}=2000 \mathrm{kN} / \mathrm{m}$,

- coefficient of elasticity of the Winkler filling $k=1100 \mathrm{MN} / \mathrm{m}^{3}$.

The results are illustrated by the graphs shown in Figures 2-8. Figures 2-4 show deflections of the upper and lower plates in dimensionless coordinates at the oscillator speed $v=50 \mathrm{~km} / \mathrm{h}$, $v=100 \mathrm{~km} / \mathrm{h}$ and $v=150 \mathrm{~km} / \mathrm{h}$. Figures 5 and 6 illustrate, respectively, the impact of the oscillator's substrate velocity and elasticity coefficient on its vertical $M$ mass displacement. In contrast, Figures $\mathbf{7}$ and $\mathbf{8}$ show the effect of the elasticity $c$ coefficient of the substrate on the deflection of the center of the upper and lower plates.

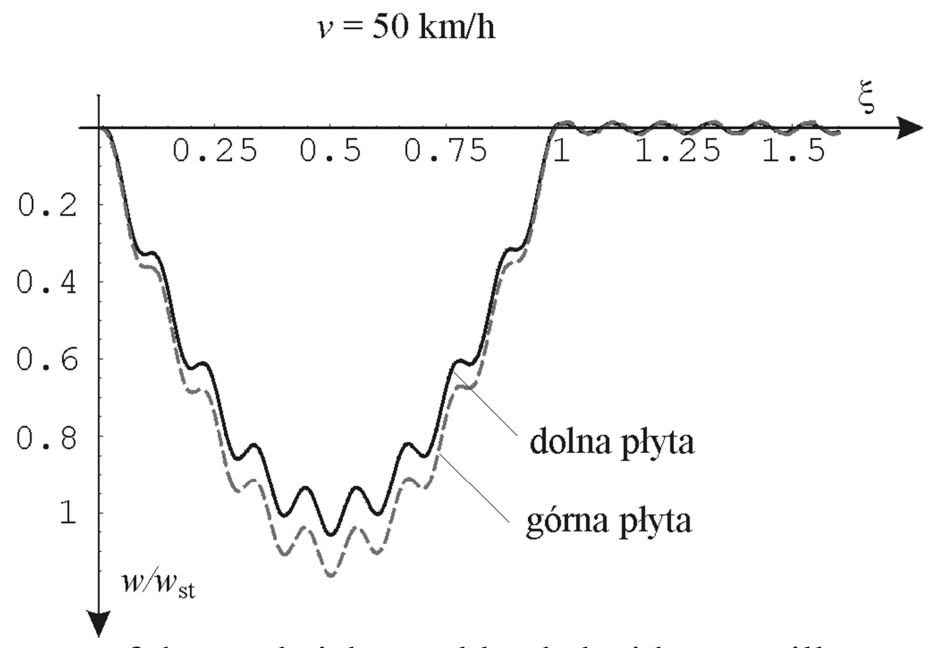

2. Bending of the center of the sandwich panel loaded with an oscillator moving at a speed of $50 \mathrm{~km} / \mathrm{h}, 0 \leq \xi \leq 1$ - forced vibrations, $\xi>1$ - free vibrations

$$
v=100 \mathrm{~km} / \mathrm{h}
$$

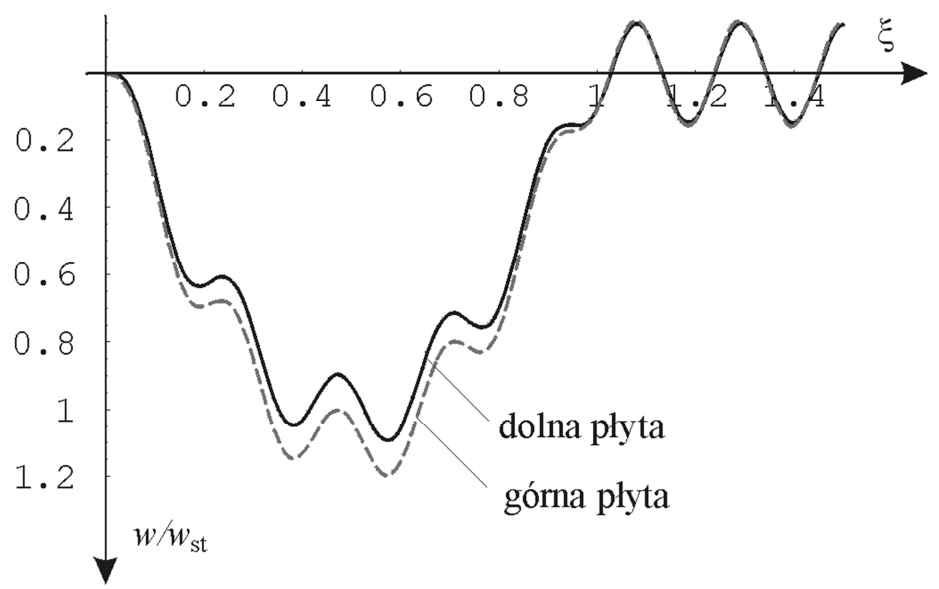

3. Bending of the center of the sandwich panel loaded with an oscillator moving at $100 \mathrm{~km} / \mathrm{h}$, $0 \leq \xi \leq 1$ - forced vibrations, $\xi>1$ - free vibrations 


$$
v=150 \mathrm{~km} / \mathrm{h}
$$

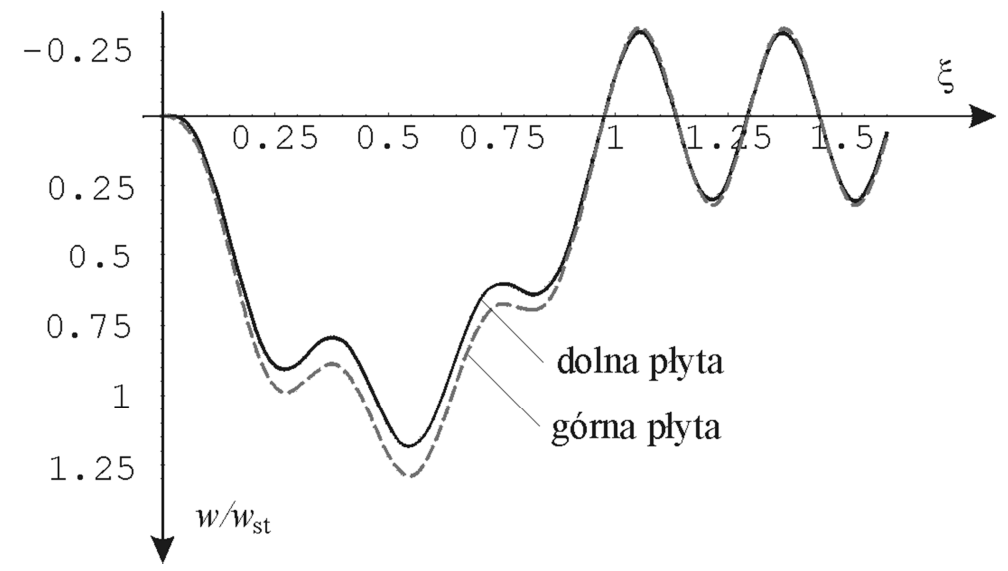

4. Bending of the center of the sandwich panel loaded with an oscillator moving at a speed of $150 \mathrm{~km} / \mathrm{h}, 0 \leq \xi \leq 1$ - forced vibrations, $\xi>1$ - free vibrations

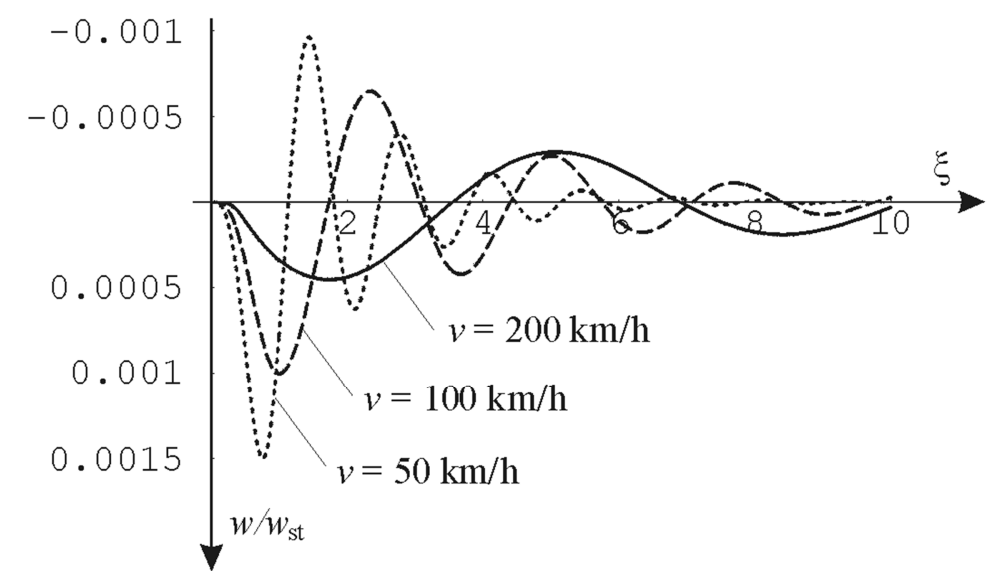

5. Impact of oscillator speed on its vertical displacement

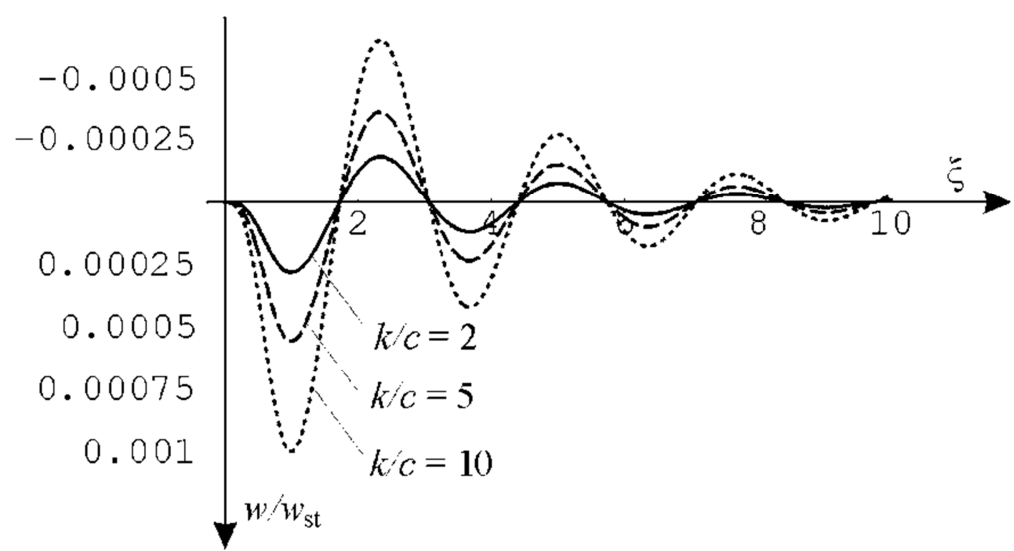

6. Influence of the substrate elasticity coefficient $c$ on the vertical displacement of the $M$ mass of the oscillator moving at speed $v=100 \mathrm{~km} / \mathrm{h}$ at a constant value of the elasticity coefficient of filling $k=1100 \mathrm{MN} / \mathrm{m}^{3}$ 


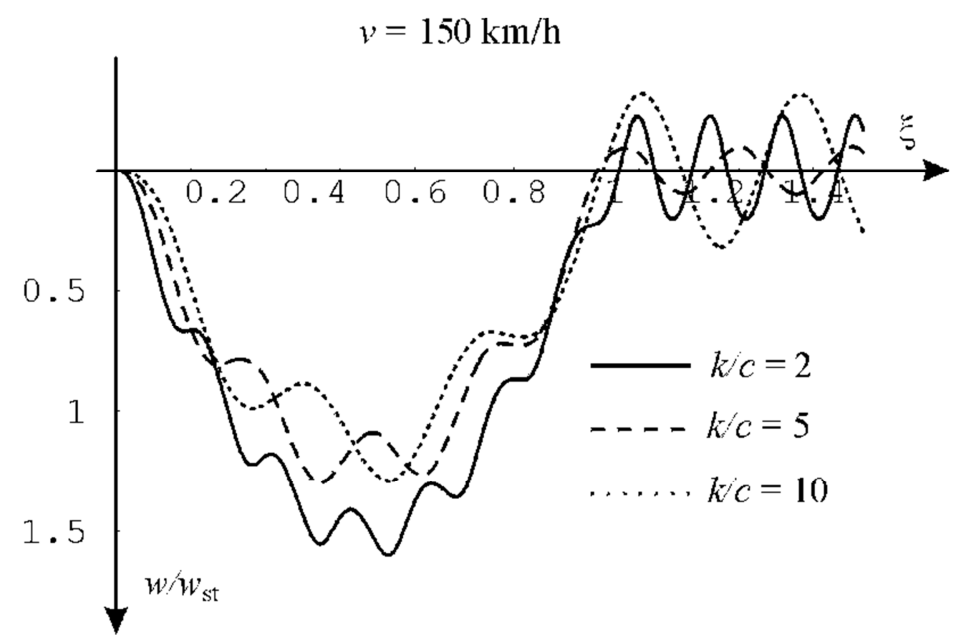

7. Influence of the elasticity coefficient $c$ of the substrate on the deflection of the center of the upper plate, the elasticity coefficient of the filling $k=1100 \mathrm{MN} / \mathrm{m}^{3}$

$v=150 \mathrm{~km} / \mathrm{h}$

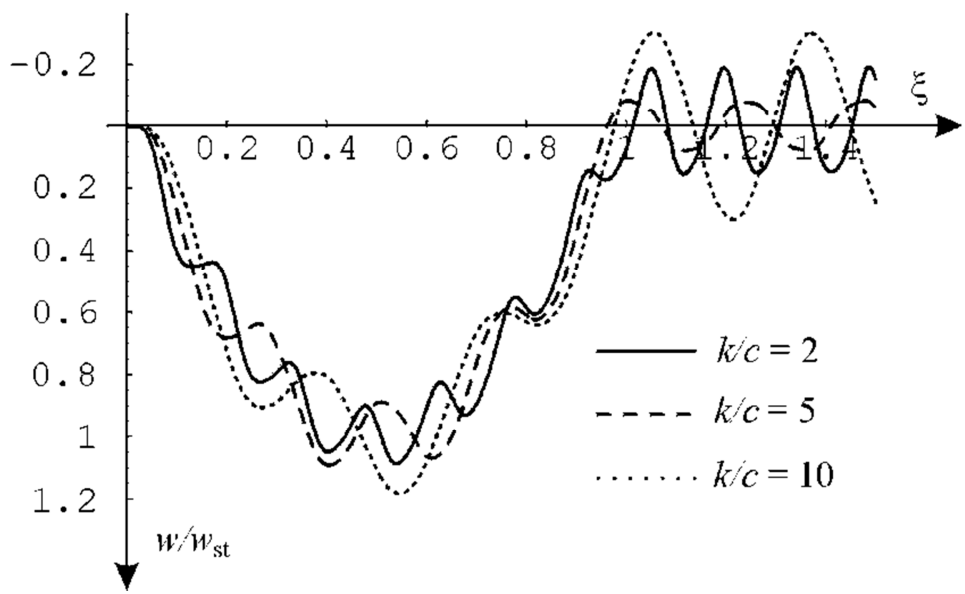

8. Influence of the elasticity coefficient $c$ of the substrate on the deflection of the center of the bottom plate, elasticity coefficient of the filling $k=1100 \mathrm{MN} / \mathrm{m}^{3}$

\section{Conclusions}

The obtained system of two dimensionless motion equations (6) is a system of ordinary, fourth order linear differential equations with variable coefficients. As a solution, we get dimensionless expressions $q_{0}(\xi)$ and $q_{11}(\xi)$ describing respectively the vertical displacement of the oscillator and the deflection of the bottom plate. Having the solution of equations (6), you can determine the deflection of the upper plate using the formula (3). The results presented in the paper can also be obtained by solving a system of three fourth order differential equations coupled to each other.

The analyzed system of plates is a bimodal system. It is possible to select the mechanical parameters of the structure in such a way that the deflections of the upper plate over which the load moves are zero. Such cases, constituting mechanical vibration dampers, were the subject of studies by, among others, Oniszczuk [5].

\section{Source materials}

[1] Ataman M. Analiza drgań belki warstwowej na podłożu Winklera obciążonej ruchomym oscylatorem. Księga Konferencyjna 11-go Seminarium Polsko- 
Ukraińskiego, Theoretical Foundations of Civil Engineering, OWPW, Warszawa 2003, str. 261-268.

[2] Fryba L. Vibration of solids and structures under moving loads. Academia, Prague 1999.

[3] Hoop T. Konstrukcje warstwowe. Arkady, Warszawa 1980.

[4] Mead D.J., Markus S. The forced vibration of a three-layer, damped sandwich beam with arbitrary boundary conditions. Journal of Sound and Vibration, 1969, 10, pp. 163-175.

[5] Oniszczuk Z. Analiza drgań złożonych układów ciągłych z więzami sprężystymi. Oficyna Wydawnicza Politechniki Rzeszowskiej, Rzeszów 1997.

[6] Rao D.K. Forced vibrations of a damped sandwich beam subjected to moving forces. Journal of Sound and Vibration, 1977, 54 (2), pp. 215-227.

[7] Szcześniak W. Drgania płyty zespolonej $\mathrm{z}$ wypełnieniem Winklera wywołane ruchomą siłą skupioną Księga Konferencyjna Seminarium Polsko-Rosyjskiego, Teoretyczne Podstawy Budownictwa, Moskwa 1996, str. 122-137.

[8] Szcześniak W. Drgania belki sandwiczowej pod wpływem ruchomego obciążenia skupionego. Prace Naukowe PW, Budownictwo, z. 132, 1998, str. 111-151.

[9] Szcześniak W. Drgania płyty sandwiczowej pod wpływem ruchomego obciążenia bezinercyjnego. Prace Naukowe PW, Budownictwo, z. 132, 1998, str. 153-172.

[10] Прусаков А.П. Устойчивость и свободные колебания трехслойных ортотропных пластин с жестким заполнителем. Проблемы устойчивости в строителной механике. Ред. В.В. Болотин, Издат. литерат. по строительству, Москва 1965. 